\title{
Arterial hypertension and lifestyle of waterway workers
}

\author{
Hipertensão arterial e estilo de vida de trabalhadores aquaviários
}

Hipertensión arterial y estilo de vida de los trabajadores marítimos

Jorge Luiz Lima da Silva ${ }^{1}$, Jonathan Henrique Anjos de Almeida ${ }^{1}$, Rafael da Silva Soares ${ }^{1}$, Monyque Evelyn dos Santos Silva ${ }^{1}$, Enéas Rangel Teixeira ${ }^{1}$, Jones Alberto de Almeida ${ }^{2}$

Objective: to describe the prevalence of arterial hypertension among workers of water transportation company in the state of Rio de Janeiro. Methods: it is a sectional study performed with 316 employees. Socio-demographic variables, labor, of lifestyle and health were analyzed; the numbers above 120/80 mmHg were considered as an initial risk for hypertension. Results: the prevalence of hypertension $(>140 / 90 \mathrm{mmHg})$ was $19.3 \%$. The prevalence of blood pressure values above $120 / 80 \mathrm{mmHg}$ was $65.5 \%$. Male gender $(\mathrm{p}=0.001)$; age over 35 years $(\mathrm{p}=0.014)$; marital status $(\mathrm{p}=0.040)$; presence of children $(p=0.013)$; permanent job $(p=0.015)$; be more than five years in the industry $(p=0.004)$, high body mass index $(p=0.001)$ and the unawareness of having high pressure $(p=0.001)$ were associated with hypertension. Conclusion: the findings contribute to the knowledge of health area of workers and provide subsidies to nursing, can perform planning activities and multidisciplinary interventions.

Descriptors: Hypertension; Occupational Health; Occupational Health Nursing.

Objetivo: descrever a prevalência da hipertensão arterial entre trabalhadores de empresa de transporte aquaviário no estado do Rio de Janeiro. Métodos: estudo seccional realizado com 316 funcionários. Foram analisadas variáveis sociodemográficas, laborais, de estilo de vida e saúde; as cifras acima de 120/80 mmHg foram consideradas como risco inicial para o acometimento de hipertensão. Resultados: a prevalência da hipertensão (>140/90mmHg) foi $19,3 \%$. A prevalência de valores pressóricos acima de $120 / 80 \mathrm{mmHg}$ foi $65,5 \%$. Estiveram associadas à hipertensão: sexo masculino $(\mathrm{p}=0,001)$; idade acima de 35 anos $(\mathrm{p}=0,014)$; situação conjugal $(\mathrm{p}=0,040)$; presença de filhos ( $\mathrm{p}=0,013)$; vínculo permanente $(\mathrm{p}=0,015)$; estar mais de cinco anos no setor $(\mathrm{p}=0,004)$, índice de massa corporal elevado $(\mathrm{p}=0,001)$ e o desconhecimento de ter pressão elevada $(\mathrm{p}=0,001)$. Conclusão: os achados contribuem para o conhecimento da área da saúde do trabalhador e fornecem subsídios à enfermagem, pode realizar planejamento de ações e intervenções multidisciplinares.

Descritores: Hipertensão; Saúde do Trabalhador; Enfermagem do Trabalho.

Objetivo: describir la prevalencia de hipertensión arterial entre trabajadores de empresa de transporte marítimo en el estado del Río de Janeiro. Métodos: estudio transversal con 316 empleados. Se analizaron variables sociodemográficas, laborales, de estilo de vida y salud; los números por encima de 120/80 mmHg han sido considerados como riesgo para aparición temprana de la hipertensión. Resultados: prevalencia de la hipertensión arterial (>140/90mmHg) fue 19,3\%. Prevalencia de valores de presión arterial por encima de 120/ 80mmHg fue 65,5\%. Estuvieron asociados con la hipertensión: sexo masculino $(\mathrm{p}=0,001)$; edad más de 35 años $(\mathrm{p}=0,014)$; estado civil $(\mathrm{p}=0,040)$; presencia de niños $(\mathrm{p}=0,013)$; enlace permanente $(\mathrm{p}$ $=0,015)$; más de cinco años en la industria $(\mathrm{p}=0,004)$, alto índice de masa corporal $(\mathrm{p}=0,001)$ y desconocimiento de tener alta presión $(\mathrm{p}=0,001)$. Conclusión: los resultados contribuyen al conocimiento de la salud de trabajadores y proporcionan subsidios a la enfermería, puede realizar planificación de actividades e intervenciones multidisciplinares.

Descriptores: Hipertensión; Salud Laboral; Enfermería del Trabajo.

\footnotetext{
${ }^{1}$ Universidade Federal Fluminense. Niterói, RJ, Brazil.

${ }^{2}$ Companhia de Concessões Rodoviárias Ponte. Niterói, RJ, Brazil.
}

Corresponding author: Jorge Luiz Lima da Silva

Rua Doutor Celestino 74, sala 51, Centro. CEP: 24020-091. Niterói, RJ, Brazil. E-mail: jorgeluizlima@gmail.com 


\section{Introduction}

The worker's health is vitally important in promoting health, developing integral care to this population, with monitoring activities, aiming at the promotion and protection of these workers and the reduction of morbidity and mortality from the models and production processes ${ }^{(1)}$. Therefore, the health care offered to this specific population, workers, must be comprehensive and resolute since, aims at preventing and treating diseases.

When it's about waterway workers, surveys are few and focused on workplace safety, hazardous conditions, work accidents and sleep deprivation. Few materials were found about the discussion of work organization considering the family context and interpersonal relations at work.

The nurse is the professional inserted in the workplace acting in agreement with the Occupational Health National Policy, considering the principles of the Unified Health System. This professional should perform promotion, protection, and prevention of health actions because health problems resulting from work are potentially preventable $e^{(1)}$.

Among the actions performed by nurses are: the elaboration and execution of plans and programs to protect workers' health; the participation of groups that perform health inquieries, surveys of professional diseases and traumatic injuries; execution and evaluation of programs for the prevention of accidents and professional or non-professional diseases and other activities ${ }^{(2)}$.

Among the diseases that affect workers' health, are included the cardiovascular, that appear as a relevant problem of globally public health because a third part of the total world population of deaths is caused by such problems ${ }^{(3)}$.

In Brazil, cardiovascular diseases are among the leading causes of death, accounting for about a third part of all deaths in 2009. Among the cardiovascular diseases, the arterial hypertension is the most prevalent. It is estimated that systemic arterial hypertension affects more than $30 \%$ of Brazilian adults $^{(4)}$.

The systemic arterial hypertension stands out among the diseases of the circulatory system. It is characterized by a multifactorial clinical condition in which a person has high and sustained levels of blood pressure. Hypertension is often associated with functional and/or structural changes in target organs such as heart, brain and kidney, and metabolic changes, which leads to increased risk of cardiovascular $\operatorname{disease}^{(5)}$.

Risk factors for the development of systemic arterial hypertension are: age, gender and ethnicity, overweight and obesity, salt intake, alcohol consumption, sedentary lifestyle, socioeconomic factors, genetics and other factors, such as the environment of a family with unhealthy lifestyle habits, very present in our world today ${ }^{(5)}$.

In addition to these risk factors, the literature indicates that factors induced by the working environment, as technological advances, the psychological pressure, little leisure time, excessive occupational activities, low wages and poor access to health care, associated with lifestyle habits contribute to the development of cardiovascular diseases ${ }^{(6)}$.

Thus, the workers' nurses must act to know existing health problems in their assisted population, so they can trace strategic actions that generate a positive impact on the workers' health ${ }^{(2)}$. The study is grounded to describe the prevalence of arterial hypertension among workers in a waterway shipping company according to their socio-demographic, labor, and lifestyle characteristics.

The multidisciplinary team that treats the patient with hypertension can be composed of doctors, nurses, nutritionists, psychologists, social workers, physiotherapists, physical education teachers, and others. As hypertension is a multifactorial clinical 
syndrome, counting with the contribution of a team of several professionals, assists in desirable behavior for the client $t^{(5,7)}$.

Thus, the treatment includes the drug therapy and promotion of proper nutrition to the disease, performing physical activities, and the provision of guidelines aimed at the empowerment of the subject.

This study aimed to describe the prevalence of systemic arterial hypertension among workers in a waterway shipping company, according to their sociodemographic, labor, and lifestyle characteristics.

\section{Method}

It is cross-sectional and observational study. The study subjects were employees of a waterway shipping company in the state of Rio de Janeiro. 316 waterway workers were interviewed, whose data collection was developed during the year 2012.

The inclusion criteria were: being an employee of the company with a labor contract and be over 18 years old. The exclusion criteria were: being on medical leave, except for cardiovascular problems. The total number of participants at the end of data collection was 316 workers.

The instrument used was self-filled questionnaire with researcher aid when needed. Skin color, gender, age, schooling, marital status, children, and income per capita were considered as variables related to socio-demographic characteristics. Regarding the employment aspect, the variables were: professional category, the number of jobs, work shift, weekly working hours, average time on the job and type of employment link.

As for the health and lifestyle of workers, the following variables were investigated: smoking; physical activity; alcohol consumption, canned, fruits, vegetables and fried foods; body mass index; blood glucose values; if had hypertension diagnosis and performing a treatment.
The auscultation method was used to measure the blood pressure. Calibrated stethoscope and sphygmomanometer were used. The used technique was in agreement with the Brazilian Society of Cardiology recommendations inserted in the VI Brazilian Guidelines for Systemic Arterial Hypertension $^{(5)}$. The value of blood pressure was analyzed, according to the stratification inserted in Primary Care Notebook of Ministry of Health No. 15. The blood pressure values were grouped into four categories: normal (up to $120 / 80 \mathrm{mmHg}$ ); a prehypertension (with values between 120-139/80$89 \mathrm{mmHg}$ ) layer that initially configures risk for the disease; stage 1 hypertension (between 140159/90-99mmHg); and stage 2 hypertension (above $160 / 100 \mathrm{mmHg})^{(8)}$.

For the analysis of body mass index, the World Health Organization adopted classification was used, inserted in the Brazilian Guidelines of Obesity ${ }^{(9)}$. According to the classification previously mentioned, those individuals considered underweight, have the body mass index less than 18.5; the normal weight has an index between 18.5 and 24.9; pre-obese between 25.0 to 29.9; individuals who are classified as obese grade 1 have the body mass index between 30 and 34.9; and obese grade 2 have index between 35 and 39.9; obese grade 3 are above 40 .

As for the glycemic values, it was considered borderline fasting blood glucose $100 \mathrm{mg} / \mathrm{SD}^{(10)}$ and normal post-prandial blood glucose up to $180 \mathrm{mg} /$ $\mathrm{SD}^{(11)}$. The measurement of Capillary Blood Glucose was performed in the workplace; for the test, it was taken a drop of blood for use in the specific device according to the biosafety and antisepsis principles.

After reviewing and coding, data were transcribed into spreadsheets by double independent typing procedure. Errors and inconsistencies were checked through the process of review and audit data. The database was built using the Statistical Package for the Social Sciences program, version 21. 
The results were represented by measures of central tendency: mean and standard deviation and analyzed by the statistical test of Chi-square association $\left(x^{2}\right)$, adopting a significance level of $5 \%$, values below this level were described in the table. For the bivariate analysis, blood pressure values were grouped into two categories: the recommended (up to $120 / 80 \mathrm{mmHg}$ ) and above the value (numbers above $120 / 80 \mathrm{mmHg})^{(8)}$. The chi-square test was used to verify differences between the categories analyzed during the bivariate analysis. The value $\mathrm{p} \leq 0.05$ was considered as significance.

The research was submitted and approved by the Ethics Committee of the University Hospital Antonio Pedro, under number 260/11, attending the Resolution 422/2012.

\section{Results}

Most workers were men (78.5\%) and concentrated in the age group below of the average of 35 years old $(65.18 \%)$, (standard deviation=13.65). Regarding the self-reported skin color, workers referred as: blacks $(14.2 \%)$, white $(35.8 \%)$, brown (48.7\%), yellow $(0.3 \%)$ and Indigenous $(0.9 \%)$. Most respondents were classified as mestizos $49.9 \%$, from the re-categorization of colors: brown, yellow and indigenous. As for schooling, 79.4\% reported studying through high school.

As for marital status, 55.4\% lived with a partner and $57.2 \%$ had children. Regarding the average income per capita, the value of up to five minimum wages at the time ( $R \$ 3,110.00)$ was found among $50.3 \%$ of subjects.

Most of the population was composed of deck sailors (44.9\%) and employees with only one job (95.2\%). There was a predominance of the day shift in the studied population (52.8\%), averaging 36 hours a week of work, and $84.2 \%$ below this value. Of the total professionals, $69.6 \%$ worked in the company for at least five years, and most (95.2\%) had a permanent job.

\section{Health and lifestyle habits of workers}

Regarding the lifestyle of the research subjects, a total of $87.3 \%$ did not smoke, $55.7 \%$ did not practice physical activities, and (58.9\%) without regular alcohol consumption. As the frequency of food intake, constantly eating canned (98.1\%), fruits (98.1\%), fried foods $(98.1 \%)$ and vegetables (95.3\%). Most of the categories $(46.2 \%)$ had a body mass index between 25 and 29.9, indicating overweight.

As for glucose, $272(86.0 \%)$ respondents had blood glucose levels in the recommended values, 44 (14.0\%) with altered glycemia.

The mean fasting glucose was found $99,74 \mathrm{mg} /$ SD (standard deviation=20.14). Fasting glycemia was obtained from 111 individuals. The values of the postprandial measure were obtained from 205 workers, averaging 114,58mg/SD (standard deviation=34.94). Therefore, it was found that the workers were with blood glucose levels within the normal range.

\section{Analysis of arterial hypertension among workers}

As for the pressure level, most subjects (65.5\%) had blood pressure levels above recommended, indicating prehypertension and hypertension grades 1 and 2 . Standing out the fact that $75.0 \%$ of employees answered that on no previous occasion any health professional warned them about their higher pressure. Workers who reported hypertension episode, 34 $(10.8 \%)$ answered that were treating in some way, while $38(12.0 \%)$ said they did not treat hypertension.

The prevalence of hypertension (blood pressure values above 140/90 $\mathrm{mmHg}$ ) among workers was $19.3 \%$. The prehypertension was the category with the highest prevalence: $46.2 \%$. Systolic blood pressure averaged $123,13 \mathrm{mmHg}(\mathrm{SD}=12.96)$ in the 316 studied workers. The following graphs show the frequency numbers of systolic and diastolic blood pressure values among the studied workers. 
Diastolic blood pressure averaged $81.34 \mathrm{mmHg}$ $(\mathrm{SD}=9.79)$. Socio-demographic variables that were statistically significant were: sex, average age, marital status and the presence of children. Concerning labor variables: the average time in labor and employment link. As for lifestyle: body mass index above the recommended and ignorance about the own high blood pressure levels $(\mathrm{p}<0.05)$. The variable body mass index was grouped into two categories; the difference remained, where those with higher pressure were overweight $(\mathrm{p}=0.001)$ (Table 1$)$.

Table 1 - Significant data about the prevalence of systemic arterial hypertension, according to sociodemographic variables, employment, and clinical data between maritime waterways

\begin{tabular}{|c|c|c|c|}
\hline Variables & $\mathbf{N}$ & n (\%) & $P$ Value \\
\hline Gender & & & 0.001 \\
\hline Female & 68 & $31(45.6)$ & \\
\hline Male & 248 & $176(71.0)$ & \\
\hline Age by average $(S D=13.65)$ & & & 0.014 \\
\hline$\geq 35$ & 206 & $125(60.7)$ & \\
\hline$>35$ & 110 & $82(74.6)$ & \\
\hline Marital status & & & 0.040 \\
\hline With partner & 175 & $123(70.3)$ & \\
\hline Without partner & 141 & $84(59.6)$ & \\
\hline Children & & & 0.013 \\
\hline Yes & 181 & $129(71.3)$ & \\
\hline No & 135 & $78(57.8)$ & \\
\hline Average work time (years) & & & 0.004 \\
\hline$\geq 5$ & 220 & $133(60.5)$ & \\
\hline$>5$ & 96 & $74(77.1)$ & \\
\hline \multicolumn{4}{|l|}{ Link type } \\
\hline Temporary & 8 & $2(25.0)$ & 0.015 \\
\hline Permanent & 308 & $205(66.6)$ & \\
\hline Body mass index & & & 0.001 \\
\hline Underweight & 3 & $1(3.3)$ & \\
\hline Normal weight & 111 & $55(49.6)$ & \\
\hline Pre-obese & 146 & $104(71.2)$ & \\
\hline Obese grade 1 & 44 & $36(81.8)$ & \\
\hline Obese grade 2 & 6 & $6(100.0)$ & \\
\hline Obese grade 3 & 6 & $5(83.3)$ & \\
\hline Weight classification & & & 0.001 \\
\hline Normal weight & 114 & $56(49.1)$ & \\
\hline Overweight & 202 & $151(74.8)$ & \\
\hline Known previous diagnosis & & & 0.001 \\
\hline Yes & 79 & $67(84.8)$ & \\
\hline No & 237 & $140(59.1)$ & \\
\hline
\end{tabular}

Subtitle: $N=$ total number of workers in the category; $\mathrm{n}=$ number of suspected workers; $\%=$ prevalence above $120 / 80 \mathrm{mmHg}$ in the category.

\section{Discussion}

The prevalence of systemic arterial hypertension in this study was $19.3 \%$ (considering greater or equal values to $140 / 90 \mathrm{mmHg}$ ). In the study, the report of hypertension among food service sector workers was $14.3 \%^{(12)}$. In a survey performed with 154 health care professionals working in prehospital care services, it was found that $33.1 \%$ of professionals had blood pressure levels considered altered, compatible with high blood pressure ${ }^{(13)}$. Another study found the prevalence of hypertension in $39.0 \%$ of 340 interviewed health workers ${ }^{(14)}$.

The prevalence of hypertension varies between 14.3 and $39.0 \%$ was noted in the studies previously cited, which shows the strength that the disease is prevalent among workers. Studies estimate that the overall prevalence of arterial hypertension is of a billion people, resulting in about 7.1 million deaths a year worldwide ${ }^{(4)}$.

There is a need to confront this reality with effective therapeutic methods, aiming the treatment of hypertension and the prevention of complications that such chronic disease can cause. Thus, there is the importance of the nurse professional to conduct public awareness activities of the population about the adoption of healthy lifestyle habits aimed at preventing the involvement of the population by hypertension and other nosocomial.

Regarding the above, it is classified at risk those individuals who have numbers higher or equal to $120 / 80 \mathrm{mmHg}^{(8)}$. Due to the preventive character of this study, referring to the quality of life of workers, this value was adopted as a determinant of risk. Thus, the following descriptive values, follow these numbers 
where the alarming prevalence of risk was $65.5 \%$.

Regarding socio-demographic variables, there was a significant association between systemic arterial hypertension and the following variables: male (71.0\%; $\mathrm{p}=0.001)$, age over 35 years old $(74.6 \%$; $\mathrm{p}=0.014)$, married $(70.3 \% ; \mathrm{p}=0.040)$ and the presence of children (71.3\%; $\mathrm{p}=0.013)$. In this study, the age found above the average (35 years), male gender was associated with the disease. The higher prevalence among men can be explained by gender being more associated with the maritime professionals.

Although the literature indicates that there are similarities between the number of cases of hypertension between men and women, hypertension is higher among men up to age 50, and the reverse after that age ${ }^{(5)}$.

It is essential to adopt health actions that achieve this specific population. The National Comprehensive Men's Health Policy points that need, because this group has a poor seeking of primary care services, compared to women, which can be attributed to cultural variables ${ }^{(15)}$.

As for labor variables, the working time average (77.1\%; $\mathrm{p}=0.004)$ and the type of employment link showed statistically significant $(66.6 \% ; \mathrm{p}=0.015)$ when analyzed with hypertension. The working time related to hypertension may be associated with mean age (35 years old), i.e., those who showed altered levels of blood pressure are older and who work for more years in the company (permanent job).

As for lifestyle and health variables, body mass index and previous diagnosis of hypertension were significantly associated. Overweight among adults $\left(2.4 \mathrm{~kg} / \mathrm{m}^{2}\right.$ more in body mass index), even in those who practice physical activity, leads to increased risk for the development of hypertension. Central obesity is also associated with blood pressure alteration. In this study, the prevalence of overweight individuals associated with hypertension was $74.8 \%$, which represent a worrying fact because overweight is also a risk factor for other morbidities such as diabetes mellitus, metabolic syndrome, and others ${ }^{(5)}$. Added to this finding the fact that these workers even with a known diagnosis of the disease, show numbers of risk, which somehow denotes that treatment needs to be reviewed.

In a study of 366 workers at a construction company, it was found a prevalence of overweight of $39.6 \%$ (145). The association of hypertension with overweight was found in $17.2 \%$ of studied subjects. The prevalence of overweight and hypertension among men was higher than women ${ }^{(16)}$. This finding is similar to this study, since the subject of this research, mostly are men and overweight.

The association between high rates of overweight and hypertension may be related to the modern lifestyle, which combines the high caloric intake and physical inactivity. Nurses should perform activities to inform individuals their real state of health, and the importance of regular physical activity linked to a balanced diet. These measures assisted in achieving appropriate body mass index and decreased cardiovascular risk.

Self-reported hypertension associated with high blood pressure levels showed statistically significant ( $p=0.001$ ) 237 of the workers who did not report high blood pressure, 140 (59.0\%) had blood pressure above the recommended $(120 / 80 \mathrm{mmHg})$, a worrying fact, because those individuals who do not have knowledge of high blood pressure, do not seek prevention and treatment, resulting in ineffective control health.

The activities that nurses should perform concerning workers assistance are: schedule and 
perform basic care actions and monitoring the Occupational Health; perform investigations in workplaces and by the worker in their home; perform an interview with an emphasis on Occupational Health; notify occupational accidents and diseases, through notification of instruments used by the health sector; plan and participate in educational activities in the field of Occupational Health ${ }^{(2,17)}$.

Based on the findings it is up to the nurse to alert the assisted population about the importance of adherence to treatment of hypertension, which aims at the reduction of blood pressure and prevention of acute and chronic complications and also frequent monitoring of their clinical condition by the multidisciplinary team.

One of the strategies that nurses can adopt is the orientation of hypertensive clients through educational strategies such as lectures, group work, meetings and group dynamics, preferably performed in the workplace, to bring such information to the whole workers group. Thus, health education would cover more employees, increasing the awareness of non-hypertensive workers about prevention measures and health promotion.

The work dynamic was a limiting factor. Data collection took place in the working hours of employees, who were interviewed before or after the shift, or during the break hours.

To avoid the bias of the healthy worker, employees were on sick leave, during the collection period, and when they returned were inserted as study participants. In addition to this, the crosssection provides only a snapshot of the prevalence among subjects with no direct relationship between cause and effect.

\section{Conclusion}

The prevalence of hypertension among the waterway shipping workers was 60 (19.3\%). Sociodemographic characteristics that showed statistical significance were: male gender, age over 35 years old, with partner and children, permanent job, more than five years on the job, high body mass index and unawareness of previous hypertension episode.

As for labor characteristics, the fact of working with a permanent job and for more than five years also were related to high blood pressure. In the lifestyle and health characteristics, body mass index and unawareness of previous hypertension episode were statistically significant when analyzed with blood pressure levels.

It emphasizes the importance of the multidisciplinary team in workers' health within companies, forming nuclei of effective work and positive impact on the health of employees covered in their professional practice. The insertion of the nurse on this team is important, with care and management activities, being resolute, assisting health care to the workers. Besides being responsible for the planning of activities in occupational health, paying attention to the health needs of their clientele and intervening by the pursuit of quality of life and health promotion within the workplace. There must be greater interest on the part of companies, in policies that prioritize not only productivity but also investing in occupational health. 


\section{Collaborations}

Silva JLL participated in the design and project or analysis and interpretation of data, article writing and relevant critical review of the intellectual content and final approval of the version to be published. Almeida JHA, Soares RS, and Silva MES participated in the design and project or analysis and interpretation of data, article writing and relevant critical review of the intellectual content. Teixeira ER and Almeida JA participated in the design and project and relevant critical review of the intellectual content.

\section{References}

1. Ministério da Saúde (BR). Portaria no 1823, de 23 de agosto de 2012. Institui a Política Nacional de Saúde do Trabalhador e da Trabalhadora. [Internet]. 2012 [citado 2015 out. 8]. Disponível em: http://bvsms.saude.gov.br/bvs/saudelegis/ gm/2012/prt1823_23_08_2012.html

2. Silva LA, Secco IAO, Dalri RCMB, Araújo SA, Romano CC, Silveira SE. Enfermagem do trabalho e ergonomia: prevenção de agravos à saúde. Rev Enferm UERJ. 2011; 19(2):317-23.

3. Pimenta AM, Kac G, Souza RRC, Ferreira LMBA, Silqueira SMF. Trabalho noturno e risco cardiovascular em funcionários de universidade pública. Rev Assoc Med Bras. 2012; 58(2):168-77.

4. Andrade JP, Mattos LAP, Carvalho AC, Machado CA, Oliveira GMM. Programa nacional de qualificação de médicos na prevenção e atenção integral às doenças cardiovasculares. Arq Bras Cardiol. 2013; 100(3):203-11.

5. Sociedade Brasileira de Cardiologia. VI Diretrizes Brasileiras de Hipertensão. Arq Bras Cardiol. 2010; 95(Supl 1):1-51.
6. Barel M, Louzada JCA, Monteiro HL, Amaral SL. Associação dos fatores de risco para doenças cardiovasculares e qualidade de vida entre servidores da saúde. Rev Bras Educ Fís Esporte. 2010; 24(2):293-303.

7. Ministério da Saúde (BR). Estratégias para o cuidado da pessoa com doença crônica: hipertensão arterial sistêmica. Brasília: Ministério da Saúde; 2013.

8. Ministério da Saúde (BR). Hipertensão arterial sistêmica. Brasília: Ministério da Saúde; 2006.

9. Associação Brasileira para o Estudo da Obesidade e da Síndrome Metabólica. Diretrizes Brasileiras de Obesidade. Itapevi: AC Farmacêutica; 2009.

10. Sociedade Brasileira de Diabetes. Diretrizes da Sociedade Brasileira de Diabetes 2014-2015. São Paulo: AC Farmacêutica; 2015.

11. American Diabetes Association. Standards of medical care in diabetes 2014. Diabetes Care. 2014; 37(Supl 1):14-80.

12. Aguiar OB, Valente JG, Fonseca MJM. Descrição sócio demográfica, laboral e de saúde dos trabalhadores do setor de alimentação dos restaurantes populares do estado do rio de Janeiro. Rev Nutr. 2010; 23(6):969-82.

13. Cavagioni L, Pierin, AMG. Cardiovascular risk among health professionals working in prehospital care services. Rev Esc Enferm USP. 2012; 46(2):395-403.

14. Pretto ADB, Pastore CA, Assunção MCF. Comportamentos relacionados à saúde entre profissionais de ambulatórios do Sistema Único de Saúde no município de Pelotas, RS. Epidemiol Serv Saúde. 2014; 23(4):635-44.

15. Couto MT, Pinheiro TF, Valença O, Machin R, Silva GSN, Gomes R. 0 homem na atenção primária à saúde: discutindo (in)visibilidade a partir da perspectiva de gênero. Interface Comun Saúde Educ. 2010; 14(33):257-70. 
16. Fernandes ACP, Vaz AB. Perfil do índice de massa corporal de trabalhadores de uma empresa de construção civil. J Health Sci Inst. 2012; 30(2):1449.
17. Marziale MHP, Hong OS, Morris JA, Rocha FLR. The Roles and Functions of Occupational Health Nurses in Brazil and in the United States. Rev Latino-am Enfermagem. 2010; 18(2):182-8. 